\title{
Oxygenic photosynthesis as a protection mechanism for cyanobacteria against iron-encrustation in environments with high $\mathrm{Fe}^{2+}$ concentrations
}

\section{Danny lonescu ${ }^{1,2 *+}$, Bettina Buchmann ${ }^{1+}$, Christine Heim ${ }^{3}$, Stefan Häusler ${ }^{1}$, Dirk de Beer ${ }^{1}$ and Lubos Polerecky ${ }^{1,4 *}$}

${ }^{1}$ Microsensor Group, Max-Planck Institute for Marine Microbiology, Bremen, Germany

2 Department of Stratified Lakes, Leibniz Institute for Freshwater Ecology and Inland Fisheries, Stechlin, Germany

${ }^{3}$ Department of Geobiology, Geoscience Center, Georg-August University of Göttingen, Göttingen, Germany

${ }^{4}$ Department of Earth Sciences - Geochemistry, Faculty of Geosciences, Utrecht University, Utrecht, Netherlands

\section{Edited by:}

Hongyue Dang, Xiamen University,

China

\section{Reviewed by:}

Kathleen Scott, University of South Florida, USA

Marie-Ėve Garneau, University of

Zurich, Switzerland

\section{*Correspondence:}

Danny lonescu, Department of

Stratified Lakes, Leibniz Institute for

Freshwater Ecology and Inland

Fisheries, IGB, Dep 3, Experimental Limnology, Alte Fischerhütte 2, OT

Neuglobsow, 16775 Stechlin,

Germany

e-mail: ionescu@igb-berlin.de;

Lubos Polerecky, Department of

Earth Sciences - Geochemistry,

Faculty of Geosciences, Utrecht

University, Budapestlaan 4, 3584

$C D$, Utrecht, Netherlands

e-mail: I.polerecky@uu.nl

these authors have contributed equally to this work.
If $\mathrm{O}_{2}$ is available at circumneutral $\mathrm{pH}, \mathrm{Fe}^{2+}$ is rapidly oxidized to $\mathrm{Fe}^{3+}$, which precipitates as $\mathrm{FeO}(\mathrm{OH})$. Neutrophilic iron oxidizing bacteria have evolved mechanisms to prevent self-encrustation in iron. Hitherto, no mechanism has been proposed for cyanobacteria from $\mathrm{Fe}^{2+}$-rich environments; these produce $\mathrm{O}_{2}$ but are seldom found encrusted in iron. We used two sets of illuminated reactors connected to two groundwater aquifers with different $\mathrm{Fe}^{2+}$ concentrations $(0.9 \mu \mathrm{M}$ vs. $26 \mu \mathrm{M})$ in the Äspö Hard Rock Laboratory (HRL), Sweden. Cyanobacterial biofilms developed in all reactors and were phylogenetically different between the reactors. Unexpectedly, cyanobacteria growing in the $\mathrm{Fe}^{2+}$-poor reactors were encrusted in iron, whereas those in the $\mathrm{Fe}^{2+}$-rich reactors were not. In-situ microsensor measurements showed that $\mathrm{O}_{2}$ concentrations and $\mathrm{pH}$ near the surface of the cyanobacterial biofilms from the $\mathrm{Fe}^{2+}{ }^{2+}$-rich reactors were much higher than in the overlying water. This was not the case for the biofilms growing at low $\mathrm{Fe}^{2+}$ concentrations. Measurements with enrichment cultures showed that cyanobacteria from the $\mathrm{Fe}^{2+}$-rich environment increased their photosynthesis with increasing $\mathrm{Fe}^{2+}$ concentrations, whereas those from the low $\mathrm{Fe}^{2+}$ environment were inhibited at $\mathrm{Fe}^{2+}>5 \mu \mathrm{M}$. Modeling based on in-situ $\mathrm{O}_{2}$ and $\mathrm{pH}$ profiles showed that cyanobacteria from the $\mathrm{Fe}^{2+}$-rich reactor were not exposed to significant $\mathrm{Fe}^{2+}$ concentrations. We propose that, due to limited mass transfer, high photosynthetic activity in $\mathrm{Fe}^{2+}$-rich environments forms a protective zone where $\mathrm{Fe}^{2+}$ precipitates abiotically at a non-lethal distance from the cyanobacteria. This mechanism sheds new light on the possible role of cyanobacteria in precipitation of banded iron formations.

Keywords: oxygenic phototrophs, Cyanobacteria, Fe(II), iron-encrustation, banded iron formations, oxygen microgradients, $\mathrm{pH}$ microgradients

\section{INTRODUCTION}

Abiotic oxidation of $\mathrm{Fe}^{2+}$ to $\mathrm{Fe}^{3+}$ and subsequent precipitation of $\mathrm{FeO}(\mathrm{OH})$ is a function of $\mathrm{pH}$ and $\mathrm{O}_{2}$ concentration, and is relatively rapid when $\mathrm{O}_{2}$ is available at circumneutral $\mathrm{pH}$ (Khalil et al., 2011). To prevent iron self-encrustation, iron oxidizing bacteria developed a variety of protection mechanisms, including formation of organic matter stalks (Chan et al., 2009; Suzuki et al., 2011) or sheaths (Van Veen et al., 1978) that provide a template for $\mathrm{FeO}(\mathrm{OH})$ nucleation. For some phototrophic iron oxidizers, a low-pH microenvironment generated by the cell's proton pumps has been suggested as a mechanism preventing iron selfencrustation (Hegler et al., 2010). Additional adaptations include a hydrophilic cell membrane with a near neutral surface charge to prevent the adhesion of $\mathrm{Fe}^{2+} / \mathrm{Fe}^{3+}$ (Saini and Chan, 2013).

Oxygenic phototrophs are often found in microbial mats in $\mathrm{Fe}^{2+}$-rich environments (Pierson et al., 1999; Brown et al., 2005, 2010; Wieland et al., 2005). It is known that when the photosynthetically active cells are densely packed in a volume where transport is limited by diffusion (e.g., in photosynthetic biofilms or mats), their activity leads to a locally increased $\mathrm{pH}$ and $\mathrm{O}_{2}$ concentration (Pierson et al., 1999; Wieland et al., 2005), which should favor locally higher rates of $\mathrm{Fe}^{2+}$ oxidation and precipitation. Yet, oxygenic phototrophs in $\mathrm{Fe}^{2+}$-rich environments have seldom been found encrusted in precipitated iron (Pierson and Parenteau, 2000). A defense mechanism against iron self-encrustation that would enable oxygenic phototrophs to thrive in $\mathrm{Fe}^{2+}$-rich environments has hitherto not been suggested. Although cyanobacteria that accumulate iron precipitates intracellularly were described from Yellowstone National Park (Brown et al., 2010), this phenomenon has not been found elsewhere.

In the $\mathrm{Fe}^{2+}$-rich environment of the Äspö Hard Rock Laboratory (HRL), Sweden, which is a man-made research tunnel, a series of flow-through reactors were set up in 2006 as 
part of a study on iron oxidizing bacteria (Ionescu et al., 2014a). Part of the reactors were connected to two aquifers that emerge from the tunnel wall at the top and bottom of the tunnel and differ markedly with respect to concentrations of dissolved $\mathrm{Fe}^{2+}$ (top: $\sim 26 \mu \mathrm{M}$, bottom: $\sim 0.9 \mu \mathrm{M}$ ). Half of the reactors were illuminated and the other half were not. After four years of undisturbed incubation, we found that inside the illuminated reactors cyanobacterial biofilms developed. Interestingly, cyanobacteria in the $\mathrm{Fe}^{2+}$-poor reactors were mostly encrusted in iron precipitates, whereas those from the $\mathrm{Fe}^{+2}$-rich reactors were not.

In this study we aimed to understand this counter-intuitive observation. Past studies showed that only some morphotypes of cyanobacteria are found encrusted in iron (Pierson and Parenteau, 2000; Parenteau and Cady, 2010) while others are not; however a mechanism to account for these differences was not suggested. Pierson et al. (1999) showed that cyanobacterial mats from iron rich environments were characterized by high photosynthetic $\mathrm{O}_{2}$ production, which was similar to our observation in the cyanobacterial biofilms growing in the $\mathrm{Fe}^{2+}$-rich reactors. Hence, we hypothesized that it is the high rate of oxygenic photosynthesis that allows cyanobacterial proliferation in the $\mathrm{Fe}^{2+}$-rich environment of the Äspö HRL. Specifically, due to mass transfer limitations, cyanobacterial photosynthesis creates a microenvironment with elevated $\mathrm{O}_{2}$ concentrations and $\mathrm{pH}$ that causes high rates of $\mathrm{Fe}^{2+}$ oxidation and precipitation at a non-lethal distance from the cells and thus prevents their iron self-encrustation.

\section{MATERIALS AND METHODS REACTORS}

The Äspö HRL is a man-made research tunnel (length $3.6 \mathrm{~km}$ ) operated since 1995 by the Swedish Nuclear Waste Management Facility (SKB) in the south-east of Sweden. The tunnel intersects several groundwater aquifers, each characterized by specific water chemistry (Laaksoharju et al., 1999; Ionescu et al., 2014a). In 2006 two sets of two illuminated reactors were connected directly to the aquifers at sites TASF (depth $460 \mathrm{~m}$ ) and TASA-1327B (depth $185 \mathrm{~m}$ ) using valves KF0069A01 and HA1327B, respectively. Only chemically inert materials such as polytetrafluoroethylene (PTFE, Teflon ${ }^{\circledR}$ ), PTFE-fiber glass, fluorinatedethylene propylene (FEP) and special PTFE-foam were used as construction materials to avoid biological contamination from the surrounding environment and chemical contamination from glass- and plastic-ware. The reactors and connection tubing were sterilized with ethanol (70\%, overnight) before underground installation. In each set, reactor 1 (R1) had an air headspace and gas exchange was allowed through a $0.2 \mu \mathrm{m}$ membrane filter. Reactor 2 (R2) did not have an air headspace, which was achieved by elevating the outflow pipe above the height of the reactor. Both reactors were illuminated using two fluorescent lamps (WL11, Brennenstuhl, Tübingen, Germany; Figure S1). Light penetrated inside the reactors through an FEP-window in the center of the lid. Irradiance behind the window was $60 \mu \mathrm{mol}$ photons $\mathrm{m}^{-2} \mathrm{~s}^{-1}$, as determined by a quantum irradiance sensor (LI-190 Quantum) connected to a light meter (LI-250, both from LI-COR Biosciences).

\section{DNA EXTRACTION AND SEQUENCING}

To characterize the composition of the cyanobacterial communities developed in the reactors, DNA was extracted as previously described (Ionescu et al., 2012). Pyrosequencing was done by MrDNA laboratories (Shallowater, TX) using general bacterial primers 27F and 519R (Lane, 1991). Sequences were analyzed using the SILVA NGS pipeline (Ionescu et al., 2012) and the SILVA 111 database (Quast et al., 2012).

\section{CULTURING}

Green cyanobacterial biomass that developed in the aerated $\mathrm{Fe}^{2+}$-poor (TASF-R1) and aerated/non-aerated $\mathrm{Fe}^{2+}$-rich (1327$\mathrm{R} 1 / \mathrm{R} 2$ ) reactors was physically separated from the rusty-orange biomass of iron oxidizing bacteria and transferred on site to sterile BG-11 medium (Rippka et al., 1979). Upon arrival to the laboratory the samples were transferred to both solid and liquid BG-11 medium and grown in constant light (irradiance 60-70 $\mu \mathrm{mol}$ photons $\mathrm{m}^{-2} \mathrm{~s}^{-1}$ ) at $15^{\circ} \mathrm{C}$ to provide light and temperature conditions close to those in their natural habitat. To allow for later microsensor measurements (see below) without the loss of added iron, cultures were allowed to grow on GF/F filters (Whatmann, diameter $47 \mathrm{~mm}$ ) that were soaked in $\mathrm{Fe}^{2+}$-free media and placed on top of pre-grown BG-11 $\left(\mathrm{Fe}^{2+}\right.$-free) agar plates. Filters were used once the green cyanobacterial biomass was visible.

\section{MICROSENSOR MEASUREMENTS}

Dissolved $\mathrm{O}_{2}$ concentration was measured with a fast-responding Clark-type microelectrode (tip diameter $\sim 30 \mu \mathrm{m}$ ). $\mathrm{pH}$ was measured using shielded liquid ion exchange glass microelectrodes. Both microsensors were constructed and calibrated as previously described (Revsbech, 1989; de Beer and Stambler, 2000). In-situ measurements were conducted either directly in the reactors or, if not possible, directly next to them, placing the biofilms in water from the respective reactor. Illumination during all experiments was provided by a Schott KL1500 lamp (Carl Zeiss AG, Göttingen, Germany), with the incident irradiance adjusted to match the value inside the reactors $\left(60 \mu \mathrm{mol}\right.$ photons $\left.\mathrm{m}^{-2} \mathrm{~s}^{-1}\right)$.

For laboratory measurements $0.5 \mathrm{~cm}$ filter stripes with a welldeveloped cyanobacterial biomass were placed in an equally wide flow-through chamber (volume $\sim 5 \mathrm{~mL}$ ) connected to a media reservoir using a peristaltic pump (Figure S2). The medium was continuously purged with $\mathrm{N}_{2}$ gas to maintain anoxic conditions. During measurements, $\mathrm{Fe}^{2+}$ was added to the media reservoir while subsamples for iron determination were periodically taken from the chamber to assure the required concentration $(1,5$, $10,30,50 \mu \mathrm{M})$ is maintained. Iron was added from an acidic $\mathrm{Fe}$ (II)Ammonium Sulfate stock solution resulting in a slight acidification of the medium $(<0.2 \mathrm{pH}$ units). Used medium was not recycled.

A similar iron addition experiment was performed also in-situ using a biofilm collected from the aerated $\mathrm{Fe}^{2+}$-poor reactor (TASF-R1). The sample was placed in a $1 \mathrm{~L}$ beaker and covered with water from the same reactor. The water was purged with $\mathrm{N}_{2}$ and iron was added to a final concentration of $25 \mu \mathrm{M}$.

In all experiments $\mathrm{Fe}^{2+}$ was measured colorimetrically using ferrozine as previously described (Riemer et al., 2004). 


\section{NanoSIMS MEASUREMENTS}

To test whether iron oxides are being precipitated inside cyanobacterial filaments in a similar way as described by Brown et al. (2010), ${ }^{57} \mathrm{Fe}^{2+}$ was added to a culture from the nonaerated $\mathrm{Fe}^{2+}$-rich reactor at a concentration of $50 \mu \mathrm{M}$. Samples were transferred to polycarbonate filters and cyanobacterial filaments were identified using auto-fluorescence. Areas that contained the filaments were marked by a laser dissection microscope (LMD7000, Leica), which allowed their later localization and identification in the nanoSIMS instrument using the built-in CCD camera. NanoSIMS analysis was performed with the nanoSIMS $50 \mathrm{~L}$ instrument (Cameca) available at the MPI Bremen. Before each analysis the sample was pre-sputtered with a $\mathrm{Cs}^{+}$primary ion beam ( $16 \mathrm{keV}, 1.1-3.5 \mathrm{pA}$ ) focused on a spot of $\sim 120 \mathrm{~nm}$ diameter for $60-90 \mathrm{~s}$. Subsequently, the same beam was scanned over the sample in a $256 \times 256$ pixel raster with a counting time of $1 \mathrm{~ms}$ per pixel, and the following ions were detected: ${ }^{12} \mathrm{C}^{-},{ }^{12} \mathrm{C}^{14} \mathrm{~N}^{-},{ }^{32} \mathrm{~S}^{-},{ }^{56} \mathrm{Fe}^{16} \mathrm{O}^{-}$, and ${ }^{57} \mathrm{Fe}^{16} \mathrm{O}^{-}$. The mass resolution power during all measurements was $>8000$. For each region of interest 30-100 planes were acquired at a raster size of $15 \times 15$ or $30 \times 30 \mu \mathrm{m}$. Data analysis was done with the Look@NanoSIMS software (Polerecky et al., 2012). As a control of the method, the same ${ }^{57} \mathrm{Fe}^{2+}$-addition experiment and nanoSIMS analysis were performed using samples from mats of iron oxidizing bacteria.

\section{$\mathrm{Fe}^{2+}$ PROFILE MODELING}

Depth profiles of $\mathrm{Fe}^{2+}$ concentrations around the biofilm surface could not be measured and were therefore modeled numerically. First, a depth profile of $\mathrm{Fe}^{2+}$ oxidation rates was calculated according to Morgan and Lahav (2007) based on the profile of $\mathrm{O}_{2}$ concentrations and $\mathrm{pH}$ measured in-situ. Subsequently, these rates were used to calculate the evolution of the $\mathrm{Fe}^{2+}$ concentration profile, starting from a flat profile (i.e., $\mathrm{Fe}^{2+}$ concentrations in the entire modeled domain equal to that measured in the reactor water). Specifically, during each time-step, the net decrease in the $\mathrm{Fe}^{2+}$ concentration at a given depth was the result of the local $\mathrm{Fe}^{2+}$ oxidation rate combined with the transport by diffusion determined from the $\mathrm{Fe}^{2+}$ concentrations above and below. $\mathrm{Fe}^{2+}$ concentrations at distances greater than the thickness of the diffusive boundary layer (DBL) were kept constant and equal to the initial concentrations during the entire calculation. DBL thickness was derived from the measured $\mathrm{O}_{2}$ profile. Calculation proceeded in time-steps of $1 \times 10^{-3} \mathrm{~s}$ until a steady state was reached. Steady state was defined when the changes in $\mathrm{Fe}^{2+}$ concentration across the entire profile fell below $10^{-6} \mu \mathrm{M}$. Equilibrium constants required for the iron speciation were corrected for the ionic strength and temperature of the specific feeding aquifer using the Davies (Davies, 1962) and Van't Hoff (Atkins, 1978) equations, respectively. Ionic strength of the different waters was calculated using Visual MINTEQ (Ver. 3.0). Iron diffusion coefficient was set to $5.82 \times 10^{-6} \mathrm{~cm}^{2} \mathrm{~s}^{-1}$ (Yuan-Hui and Gregory, 1974). As no $\mathrm{pH}$ profile was available from the aerated $\mathrm{Fe}^{2+}$-rich reactor, modeling was done only for biofilms from the non-aerated $\mathrm{Fe}^{2+}$-rich and aerated $\mathrm{Fe}^{2+}$-poor reactors.

\section{RESULTS WATER CHEMISTRY}

Water in the top aquifer is mainly influenced by the Baltic Sea and recent meteoric water and has a retention time in the bedrock of several weeks (Laaksoharju et al., 1999). It is rich in dissolved $\mathrm{Fe}^{2+}$ (around $26 \mu \mathrm{M}$ ) and has $\mathrm{pH}$ of 7.4 and $\mathrm{O}_{2}$ concentrations of about $2 \mu \mathrm{M}$. In contrast, water in the bottom aquifer is a mixture of glacial, ancient marine and brine water and was dated to the Boreal age (SICADA, SKB Database). It has markedly lower $\mathrm{Fe}^{2+}$ concentrations $(0.9 \mu \mathrm{M})$, higher $\mathrm{pH}(8)$, and $\mathrm{O}_{2}$ concentrations of about $4 \mu \mathrm{M}$. Other notable differences include dissolved inorganic carbon (DIC), total alkalinity (Alk), and total dissolved salt (TDS) concentrations, which are about 10- and 100-fold lower and 5 -fold higher in the bottom aquifer, respectively (Table 1).

\section{IN-SITU BIOMASS}

Filamentous cyanobacteria in the aerated reactors connected to the $\mathrm{Fe}^{2+}$-poor aquifer formed veil-like biofilms $(2-3 \mathrm{~cm}$ long, 2-3 mm thick) that slowly but continuously moved due to the slow water flow in the reactor. Their pale-green color coincided with a low chlorophyll $a(\mathrm{Chl} a)$ concentration $(0.2 \mu \mathrm{g}$ Chl $a \mathrm{mg}^{-1}$ wet weight) and thus presumably low cyanobacterial biomass. Microscopic observations of biofilm subsamples revealed clear iron encrustation and largely diminished autofluorescence of the filaments (Figures 1A,B). Upon addition of $0.3 \mathrm{M}$ oxalic acid, most of the Fe-oxide crystals dissolved and the red auto-fluorescence induced by green light, which is typical for cyanobacteria due to their Chl $a$ and phycocyanin content, significantly increased (Figures 1C,D). Due to an extremely low biomass, biofilms from the non-aerated reactor from the $\mathrm{Fe}^{2+}$-poor site were not studied.

Table 1 | Physico-chemical characteristics of the different aquifers connected to the reactors.

\begin{tabular}{|c|c|c|c|c|c|c|c|c|c|c|c|c|}
\hline Site & $\begin{array}{l}\text { Sampled } \\
\text { water }\end{array}$ & pH & $\begin{array}{c}\mathbf{T} \\
{ }^{\circ} \mathbf{C}\end{array}$ & $\begin{array}{r}\mathrm{Fe}^{2+} \\
\mu \mathrm{M}\end{array}$ & $\begin{array}{c}\mathbf{O}_{2} \\
\mu M\end{array}$ & $\begin{array}{l}\text { Alk } \\
\mu \mathrm{M}\end{array}$ & $\begin{array}{c}\text { DIC } \\
\mu \mathrm{M} C\end{array}$ & $\begin{array}{c}\text { DOC } \\
\mu M C\end{array}$ & $\begin{array}{c}\text { TDS } \\
\mathrm{g} / \mathrm{l}\end{array}$ & $\begin{array}{l}\mathrm{H}_{2} \mathrm{~S} \\
\mu \mathrm{M}\end{array}$ & $\begin{array}{l}\mathrm{NH}_{4} \\
\mu \mathrm{M}\end{array}$ & $\begin{array}{l}\mathrm{NO}_{3} \\
\mu \mathrm{M}\end{array}$ \\
\hline TASF (Fe ${ }^{2+}$-poor) & Aquifer & 7.98 & 12 & 0.89 & 3.7 & 110 & 133 & 183 & 23.6 & 0.53 & 0.61 & 1.05 \\
\hline \multirow[t]{3}{*}{ TASA (1327 B Fe $2+$-rich) } & Aquifer & 7.41 & 15 & 25.8 & 2.2 & 3277 & 1691 & 492 & 5.1 & 1.88 & 215 & 0.12 \\
\hline & $\mathrm{R} 1^{\#}$ & 7.40 & 15 & 27.1 & 7.2 & 3277 & 1933 & 617 & 5.1 & 1.17 & 217 & 1.15 \\
\hline & $\mathrm{R}^{\#}{ }^{\#}$ & 7.39 & 15 & 26.4 & 3.9 & 3245 & 1825 & 558 & 4.9 & 0.88 & 212 & 1.48 \\
\hline
\end{tabular}

${ }^{\#} R 1$ and $R 2$ are aerated and non-aerated flow reactors, respectively. 


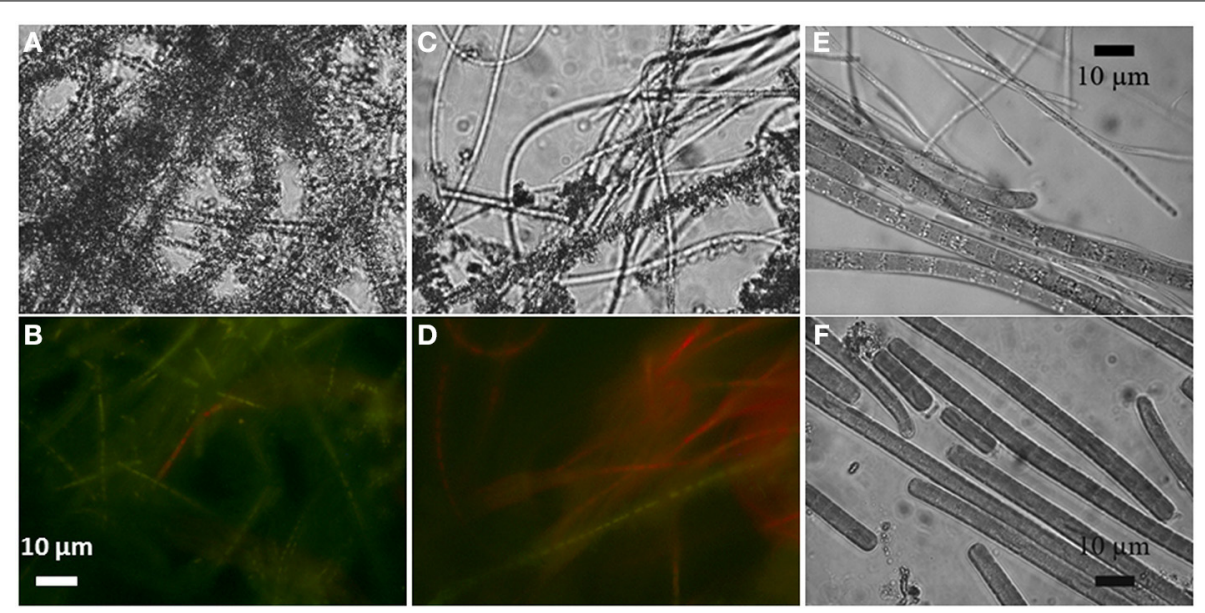

FIGURE 1 | Light (A) and autofluorescence (B) microscopic images of iron-encrusted cyanobacterial filaments from the aerated $\mathrm{Fe}^{2+}$-poor reactor. Upon treatment with $0.3 \mathrm{M}$ oxalic acid most of the Fe crystals dissolved (C) and the natural red autofluorescence induced by green light resumed (D). Filaments from the aerated (E) and non-aerated (F) Fe $\mathrm{Fe}^{2+}$-rich reactors were not found encrusted.
Cyanobacterial biofilms in the reactors connected to the $\mathrm{Fe}^{2+}$-rich aquifer had about 10 -fold larger biomass $(3.2 \mu \mathrm{g} \mathrm{Chl}$ $a \mathrm{mg}^{-1}$ wet weight), consistent with their dark-green appearance. Biofilms in the aerated reactor were $0.5-1 \mathrm{~mm}$ thick, floated atop of black decaying material $(2-3 \mathrm{~cm}$ thick) and were in direct contact with air in the reactor (but still moist). In contrast, cyanobacterial biofilms in the non-aerated reactor were submersed, about $0.3 \mathrm{~mm}$ thick, and covered thick mats of iron oxidizing bacteria, the latter identified based on their rusty-orange appearance and an in-depth community analysis performed earlier (Ionescu et al., 2014a). Importantly, no signs of iron encrustation were observed for the cyanobacteria from these two reactors (Figures 1E,F).

\section{CYANOBACTERIAL COMMUNITY}

Phylogenetic comparison based on the gene for the 16S rRNA revealed that the cyanobacterial communities significantly differed between the reactors from the $\mathrm{Fe}^{2+}$-rich and $\mathrm{Fe}^{2+}$-poor sites (Figure S3). Communities from the aerated and nonaerated reactors from the $\mathrm{Fe}^{2+}$-rich site were more diverse, clustering with sequences of Geitlerinema, Pseudanabaena, and several different clusters of Leptolyngbia. Many sequences from these reactors were shared. In contrast, cyanobacterial sequences from the aerated reactor from the $\mathrm{Fe}^{2+}$-poor site were unique, forming a cluster within the clade of Leptolyngbia (Figure S3). No sequences from any of the sampled reactors were closely related with the known ferro-philic cyanobacteria Chroogloeocystis siderophila. Sequences of cyanobacterial enrichment cultures from the respective reactors clustered in close proximity to those obtained from in-situ samples. One of these sequences was closely related to Oscillatoria JSC-1, a cyanobacterial strain known to precipitate iron internally (Brown et al., 2010).

Clustering of the sequences at $98 \%$ similarity cutoff using the CDHIT-EST software(Huang et al., 2010; Fu et al., 2012) supports the phylogenetic tree and shows that no overlap is found between sequences from the $\mathrm{Fe}^{2+}$-poor and the $\mathrm{Fe}^{2+}$-rich reactors. In contrast, sequences from the $\mathrm{Fe}^{2+}$-rich aerated and non-aerated reactors form individual as well as shared clusters (data not shown).

\section{$\mathrm{O}_{2}$ AND $\mathrm{pH}$ MICROSENSOR MEASUREMENTS}

In-situ microsensor measurements revealed high volumetric rates of oxygenic photosynthesis in the biofilms forming in the $\mathrm{Fe}^{2+}$ rich reactors. This was demonstrated by the steep gradients in $\mathrm{O}_{2}$ and $\mathrm{pH}$ around the biofilm-water interface (Figure 2) as well as by direct rate measurements using the light-dark-shift method of Revsbech and Jorgensen (1981) (Figure S4). In contrast, $\mathrm{O}_{2}$ and $\mathrm{pH}$ profiles had only minute peaks in the biofilms in the $\mathrm{Fe}^{2+}$-poor reactor (Figure 2), indicating very low rates of photosynthesis. Based on the measured $\mathrm{O}_{2}$ profiles, the estimated net areal rates of photosynthesis were $21-23$ and $1.5-$ $5 \mu \mathrm{mol} \mathrm{m}{ }^{-2} \mathrm{~s}^{-1}$ in the biofilms from the $\mathrm{Fe}^{2+}$-rich and $\mathrm{Fe}^{2+}$. poor reactors, respectively. This pattern was consistent with the approximately 10 -fold difference in the cyanobacterial biomass (see above).

We used freshly collected subsamples of the biofilms from the $\mathrm{Fe}^{2+}$-poor reactor to test the response of their photosynthesis to the addition of $\mathrm{Fe}^{2+}$ at a concentration comparable to that found in the $\mathrm{Fe}^{2+}$-rich reactors. We found that the photosynthetic $\mathrm{O}_{2}$ production started to decrease within minutes after the increase of the $\mathrm{Fe}^{2+}$ concentration to $25 \mu \mathrm{M}$ and was close to zero after about an hour (Figure S5).

In addition to in-situ measurements, we conducted laboratory microsensor measurements to characterize the response of photosynthesis to increased $\mathrm{Fe}^{2+}$ concentrations in biofilms prepared from the cyanobacterial enrichment cultures obtained from the two reactor types. When the bulk $\mathrm{pH}$ was 7.1, the addition of up to $50 \mu \mathrm{M} \mathrm{Fe}^{2+}$ stimulated net $\mathrm{O}_{2}$ production in the enrichment cultures from the non-aerated $\mathrm{Fe}^{2+}$-rich reactor (Figure 3A open triangles; Spearman correlation coefficient $\rho=0.952$, $p=2 \times 10^{-7}$ ), suggesting stimulation of photosynthetic activity by $\mathrm{Fe}^{2+}$. This was consistent with the observed increase in 

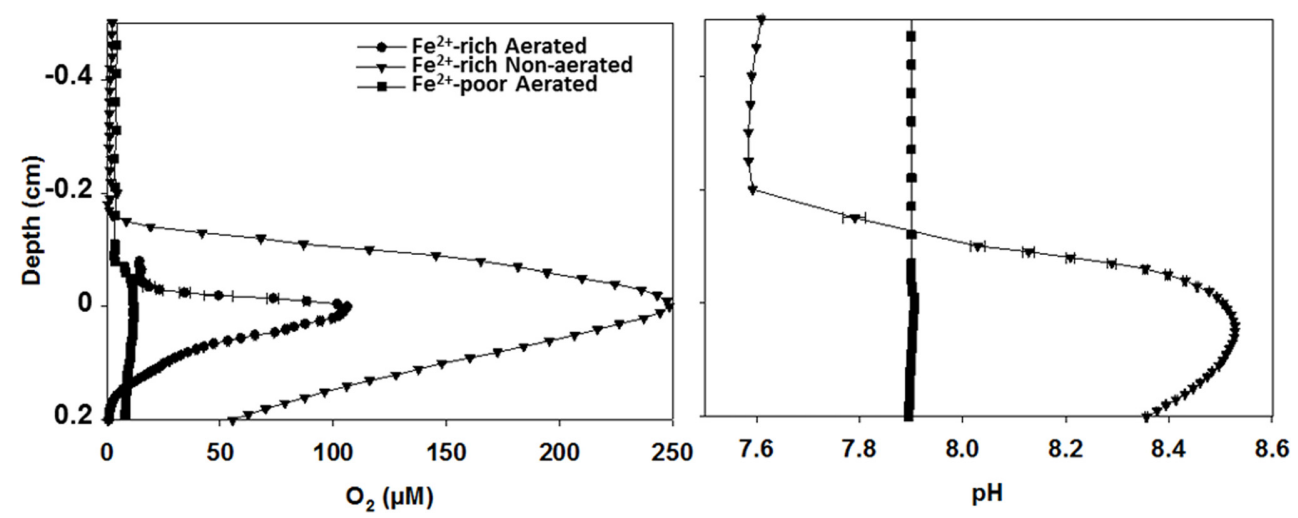

FIGURE 2 | In-situ $\mathrm{O}_{2}$ and pH microprofiles in cyanobacterial biofilms from aerated and non-aerated $\mathrm{Fe}^{2+}$-rich and aerated $\mathrm{Fe}^{2+}$-poor reactors. All profiles were measured under similar irradiance as that used during long-term incubations of the reactors. Measurements in the biofilm from the aerated $\mathrm{Fe}^{2+}$-poor reactor were conducted outside of the reactor using the natural water purged with $\mathrm{N}_{2}$ gas to maintain anoxic conditions.
$\mathrm{pH}$ gradients at the biofilm-medium interface (Figure 3A, filled triangles; $\rho=0.854, p=2 \times 10^{-7}$ ). In contrast, increasing $\mathrm{Fe}^{2+}$ lead to a decrease in both $\mathrm{O}_{2}$ fluxes and $\mathrm{pH}$ gradients in biofilms prepared from the enrichment cultures from the aerated $\mathrm{Fe}^{2+}$ rich $\left(\mathrm{O}_{2}: \rho=-0.686, p=7.45 \times 10^{-4} ; \mathrm{pH}: \rho=-0.741, p=\right.$ $0.011)$ and $\mathrm{Fe}^{2+}$-poor reactor $\left(\mathrm{O}_{2}: \rho=-0.865, p=2 \times 10^{-7}\right.$; $\left.\mathrm{pH}: \rho=-0.986, p=2 \times 10^{-7}\right)$, with the largest part of this decrease occurring for $\mathrm{Fe}^{2+}$ concentrations between 1 and $10 \mu \mathrm{M}$ (Figures 3A,B). Analysis of covariance (ANCOVA) revealed that the slope of the regression line for the culture enriched from the non-aerated $\mathrm{Fe}^{2+}$-rich reactor was significantly greater than that for the enrichment cultures from the aerated $\mathrm{Fe}^{2+}$-rich and aerated $\mathrm{Fe}^{2+}$-poor reactors $\left(p=2 \times 10^{-9}\right)$, whereas the latter two were not significantly different $(p=0.97)$.

When the same experiments were performed at bulk medium $\mathrm{pH}$ of 8 , net $\mathrm{O}_{2}$ production was again significantly stimulated by $\mathrm{Fe}^{2+}$ in the biofilm cultures from the non-aerated $\mathrm{Fe}^{2+}$ reactor $(\rho=0.716 ; p=0.015)$, while no significant inhibition was observed in the biofilms from the aerated $\mathrm{Fe}^{2+}$-rich $(\rho=0.543 ; p=0.097)$ and aerated $\mathrm{Fe}^{2+}$-poor $(\rho=-0.123 ; p=$ 0.707 ) reactors (Figures 3C,D). However, due to the high variability in the results, the slopes of the regression lines for the three biofilm types were not significantly different (ANCOVA, $p=0.079$ ). Also, there was no significant difference in the slopes determined at $\mathrm{pH} 7.1$ and 8 in the biofilm cultures from the $\mathrm{Fe}^{2+}$-rich reactors (ANCOVA, aerated $p=0.20$; non-aerated $p=0.26$ ).

Importantly, no encrustation in iron minerals was observed in any $(\mathrm{pH} 7.1$ or $\mathrm{pH} 8.0)$ of these experiments.

\section{NanoSIMS MEASUREMENTS}

No iron precipitates could be detected in or nearby the cyanobacterial filaments from the non-aerated $\mathrm{Fe}^{2+}$-rich reactor which were incubated with ${ }^{57} \mathrm{Fe}^{2+}$ (Figures S6A,B). This is in contrast to control experiments conducted with samples from mats of iron oxidizing bacteria where some cells were clearly enriched in ${ }^{57} \mathrm{Fe}$ precipitates as compared to the surrounding (Figures S6C,D; see also Ionescu et al., 2014b).

\section{$\mathrm{Fe}^{2+}$ PROFILE MODELING}

Modeling in the non-aerated $\mathrm{Fe}^{2+}$-rich reactor revealed that the steady state $\mathrm{Fe}^{2+}$ concentration profile was reached in $\sim 10 \mathrm{~min}$. $\mathrm{Fe}^{2+}$ concentration at the biofilm surface decreased from the initial value of $30 \mu \mathrm{M}$ to below $0.001 \mu \mathrm{M}$ in about $20 \mathrm{~s}$, and in the steady state the $\mathrm{Fe}^{2+}$ concentration was below $0.001 \mu \mathrm{M}$ already at a distance of $\sim 400 \mu \mathrm{m}$ from the biofilm surface (Figure $4 \mathrm{~A}$ ). In contrast, in the aerated $\mathrm{Fe}^{2+}$-poor reactor the steady state was reached after a much longer time $(\sim 2 \mathrm{~h})$ and the concentration at the biofilm surface did not decrease below $0.3 \mu \mathrm{M}$ (Figure 4B).

\section{DISCUSSION}

The role of cyanobacterial oxygenic photosynthesis has been extensively discussed in relation to $\mathrm{Fe}$ (III) mineral formation during early Earth (Cloud, 1973; Lewy, 2012). However, the effects of $\mathrm{O}_{2}$ production in the presence of high ferrous iron concentrations have been only seldom discussed on the scale relevant for the microenvironment of the cyanobacteria ( $\sim 100 \mu \mathrm{m}$ or less) (Pierson and Parenteau, 2000). Our finding of iron-encrusted cyanobacteria at low $\mathrm{Fe}^{2+}$ concentrations as compared to naked filaments at high $\mathrm{Fe}^{2+}$ concentrations has raised three intriguing questions: (1) Why do we see iron-encrusted filaments specifically in the environment with the lower $\mathrm{Fe}^{2+}$ ? (2) How do oxygenic phototrophs, who by their means of existence form environmental conditions favoring Fe precipitation, avoid encrustation? (3) How do these organisms avoid $\mathrm{Fe}^{2+}$ toxicity?

Cyanobacteria are regarded as oxygenic phototrophs, yet a large number of species possess the ability to switch to anoxygenic phototrophy in the presence of sulfide (Cohen et al., 1986; Oren et al., 2005). Therefore, one possible way for photosynthetic cyanobacteria to avoid iron encrustation in $\mathrm{Fe}^{2+}$-rich environments could be by performing anoxygenic photosynthesis utilizing $\mathrm{H}_{2} \mathrm{~S}$ (detected in the reactors) as the electron donor, which does not lead to $\mathrm{O}_{2}$ production. Alternatively, it was suggested that cyanobacteria could also use $\mathrm{Fe}^{2+}$ as an electron donor in the process of anoxygenic photosynthesis (Olson, 2006). Such cyanobacteria have, however, not been described yet. If such a mechanism exists, it is not clear where would the oxidized $\mathrm{Fe}$ 

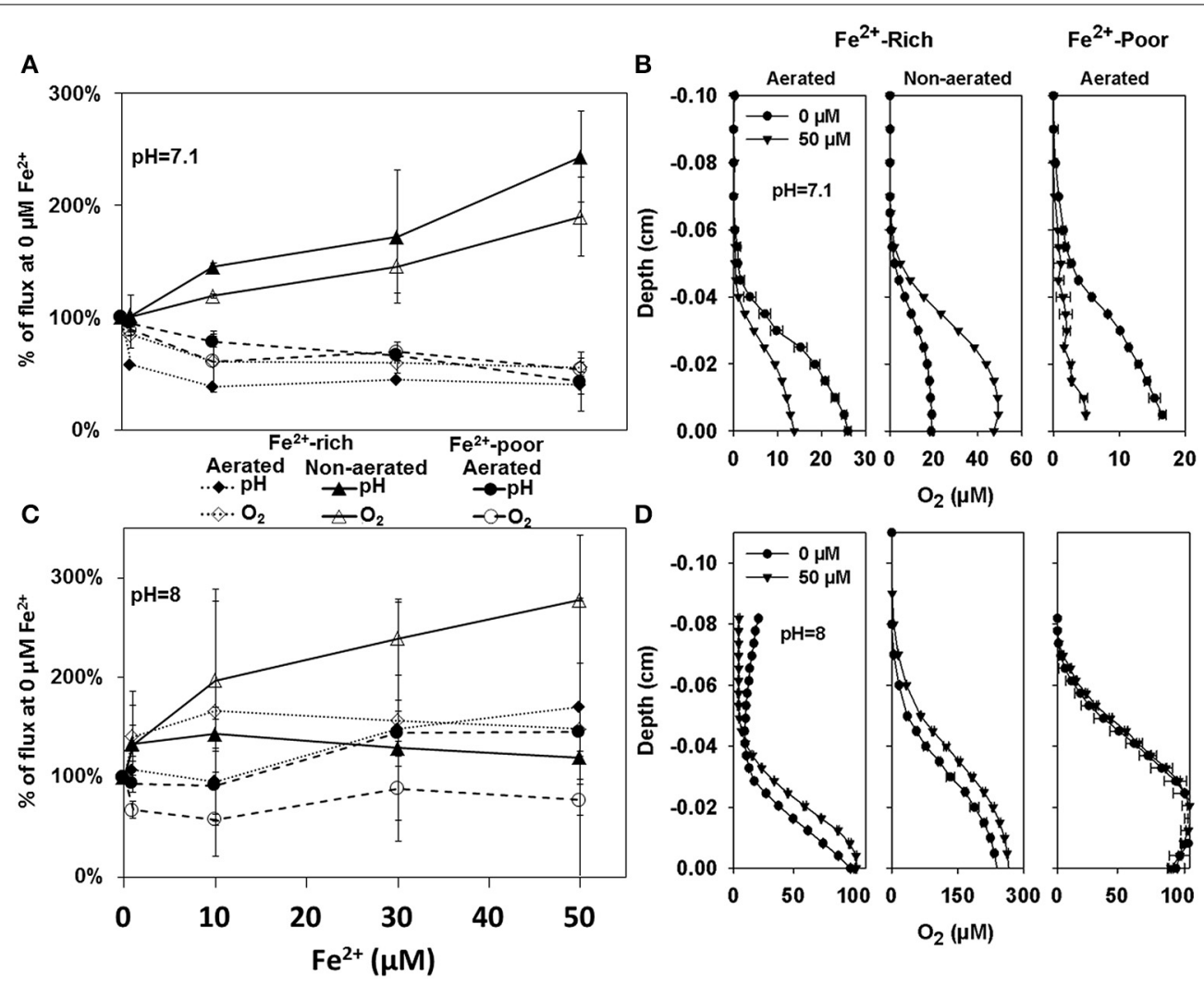

D

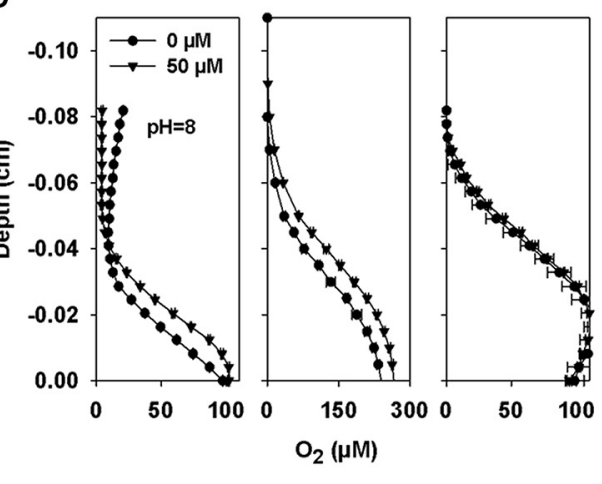

FIGURE 3 | Percent change in $\mathrm{O}_{2}$ fluxes and $\mathrm{pH}$ gradients calculated from microprofiles measured in cyanobacterial biofilms grown from enrichment cultures from the $\mathrm{Fe}^{2+}$-rich and $\mathbf{F e}^{2+}$-poor reactors at $\mathbf{p H} 7$ (A) and $\mathbf{p H} 8$ (C). The shown fluxes are averaged measurements in 3 different biofilms with 3-4 steady state profiles each. Example of profiles from which these fluxes were calculated are shown in (B,D), respectively. Depth zero corresponds to the biofilm surface. be deposited, as the analogous sulfide oxidizing phototrophs can deposit elemental sulfur both internally (Arunasri et al., 2005) and externally (Ventura et al., 2000).

With this background knowledge, we initially hypothesized that the cyanobacteria in the $\mathrm{Fe}^{2+}$-rich reactors performed anoxygenic photosynthesis. This hypothesis was rejected by our in-situ microsensor measurements, which clearly showed that they performed oxygenic photosynthesis. This was further supported by our failed attempts to grow the cultured cyanobacteria in the presence of DCMU (3-(3,4-dichlorophenyl)-1,1-dimethylurea), an inhibitor of oxygenic photosynthesis, using either sulfide or iron as the electron donor, questioning the ability of these cyanobacteria to perform anoxygenic photosynthesis.

Recently it was shown that some filamentous cyanobacteria from iron-rich environments accumulate iron-oxides internally (Brown et al., 2010). These cyanobacteria are not full with iron particles as one would expect from an organism that is continuously exposed to high $\mathrm{Fe}^{2+}$ concentrations. Therefore, it may be that the creation of iron inclusions is an auxiliary mechanism only. Our NanoSIMS measurements did not detect any accumulation of iron oxides inside the cyanobacteria cells from the Äspö HRL (Figure S6). Such an accumulation would have accounted for the lack of external iron precipitates and may have provided a detoxification mechanism.
The above results call for a different mechanism to prevent encrustation in iron while actively producing $\mathrm{O}_{2}$. We suggest that, counter-intuitively, it is the photosynthetic activity itself, in combination with mass transfer limitation, that protects cyanobacteria against iron encrustation.

Our data show that each of the three cyanobacterial communities sampled is adapted to the iron concentrations it lives in. Oxygen production by the cyanobacteria enriched from the $\mathrm{Fe}^{2+}$-poor reactor is inhibited by more than $1 \mu \mathrm{M} \mathrm{Fe}^{2+}$, yet they never encounter higher concentrations in their natural habitat. To confirm that this is true also for the original biofilm community from the $\mathrm{Fe}^{2+}$-poor reactor and not only a trait of the enriched cyanobacteria, we exposed freshly collected biofilms to iron concentrations present in the $\mathrm{Fe}^{2+}$-rich reactors. As expected, photosynthesis was inhibited within minutes of the exposure. Intriguingly, the observed decline in oxygen production was coupled with a transient increase in $\mathrm{pH}$ at the biofilm surface (Figure S5) for which we presently do not have an explanation.

The cyanobacteria from the aerated $\mathrm{Fe}^{2+}$-rich reactor exhibit as well a reduced $\mathrm{O}_{2}$ production when exposed to more than $1 \mu \mathrm{M} \mathrm{Fe}^{2+}$ (at $\mathrm{pH} 7.1$ ). Though they grow in a reactor connected to an aquifer with high ferrous iron concentration, the cyanobacterial biofilms from the aerated $\mathrm{Fe}^{2+}$-rich reactors are found only floating at the reactor water surface atop mats of $\mathrm{Fe}^{2+}$ oxidizers, 

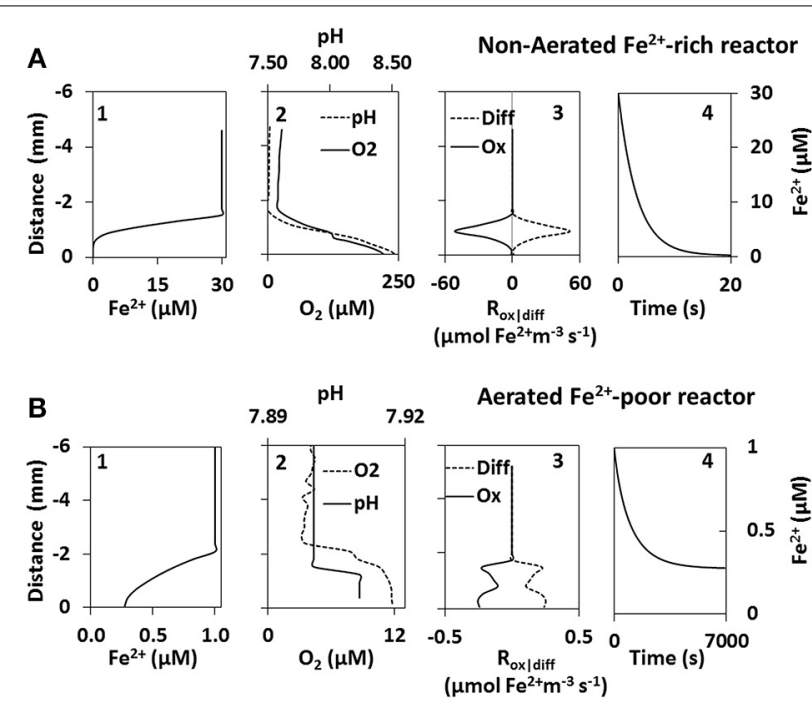

FIGURE $4 \mid \mathrm{Fe}^{2+}$ model results of the non-aerated $\mathrm{Fe}^{2+}$-rich (A) and aerated $\mathrm{Fe}^{2+}$-poor (B) reactors. Steady state $\mathrm{Fe}^{2+}$ profiles above cyanobacteria biofilms (graph 1) were calculated using microprofiles of $\mathrm{O}_{2}$ and $\mathrm{pH}$ measured in-situ (graph 2). Steady state was achieved once $\mathrm{Fe}^{2+}$ consumption by abiotic oxidation $(\mathrm{Ox})$ was equal to $\mathrm{Fe}^{2+}$ supplied by diffusion (Diff) (graph 3). The change in $\mathrm{Fe}^{2+}$ concentration at the biofilm surface is shown as a function of time (graph 4 ).

where they are not in direct contact with the aquifer water and therefore also with high $\mathrm{Fe}^{2+}$ concentrations.

Notably, the inhibitory effects of iron observed in cultures from the aerated $\mathrm{Fe}^{2+}$-rich and $\mathrm{Fe}^{2+}$-poor reactors at $\mathrm{pH} 7.1$ were not present when the experiment was conducted at $\mathrm{pH} 8$. At this $\mathrm{pH} \mathrm{Fe}$ is expected to precipitate faster and thus the cells are not exposed to high concentrations at any time. Nevertheless, the cyanobacteria from the $\mathrm{Fe}^{2+}$-poor reactor still get encrusted in iron at a $\mathrm{pH}$ of 7.9. This phenomenon is explained by the results of our model as discussed later on.

In contrast to the biofilms from the aerated $\mathrm{Fe}^{2+}$-rich and $\mathrm{Fe}^{2+}$-poor reactors, the submerged cyanobacterial biofilms from the non-aerated $\mathrm{Fe}^{2+}$-rich reactor increase their $\mathrm{O}_{2}$ production in response to increasing iron concentration. Nevertheless, despite their tolerance to elevated $\mathrm{Fe}^{2+}$ concentrations, these are not required for growth in culture as also confirmed by their continuous activity at all tested $\mathrm{Fe}^{2+}$ concentrations.

Modeling of $\mathrm{Fe}^{2+}$ concentrations in the non-aerated $\mathrm{Fe}^{2+}$-rich reactor suggests that all $\mathrm{Fe}^{2+}$ is precipitated at a distance of at least $400 \mu \mathrm{m}$ from the biofilm surface. Thus, at steady state the cyanobacteria forming the biofilm are not exposed to high $\mathrm{Fe}^{2+}$ in their microenvironment. The precipitated $\mathrm{Fe}$ (oxy)hydroxides are probably dispersed away by the water movement. Although true steady state conditions would be reached rather slowly (in $\sim 10 \mathrm{~min}$ ), our simulation suggests that already after about $20 \mathrm{~s}$ the biofilm is exposed to little or no $\mathrm{Fe}^{2+}$ at all. This suggests the necessity for these cyanobacteria to be able to tolerate high $\mathrm{Fe}^{2+}$ concentrations for at least a short period of time (seconds to minutes).

The cyanobacteria in the aerated $\mathrm{Fe}^{2+}$-poor reactor are not able to precipitate the $\mathrm{Fe}^{2+}$ away from their surface. Even if a theoretical steady-state were reached, which would take about
$2 \mathrm{~h}, \mathrm{Fe}^{2+}$ concentrations inside the biofilm would still be about $0.3 \mu \mathrm{M}$. Given the low biomass and the continuous movement of the biofilm, such a steady-state condition can, however, never be reached. Thus, given the already high $\mathrm{pH}$ in the water column of this reactor, whatever $\mathrm{O}_{2}$ these cyanobacteria produce reacts immediately with the available $\mathrm{Fe}^{2+}$ and precipitates on the filaments themselves. Furthermore, $\mathrm{Fe}^{2+}$ is known to bind to charged moieties of extracellular polymeric substances (Fortin and Langley, 2005). Therefore, the continuous movement of the biofilms coupled with the low $\mathrm{O}_{2}$ production will additionally lead to the adherence of Fe to the filaments. Though these cyanobacteria are able to achieve high biomass in $\mathrm{Fe}^{2+}$-poor culture media, an increase in $\mathrm{Fe}^{2+}$ above $1 \mu \mathrm{M}$ inhibits their growth. Therefore these organisms are confined to environments with low $\mathrm{Fe}^{2+}$.

High photosynthesis rates appear to be a common trait of benthic cyanobacterial communities described from environments with high $\mathrm{Fe}^{2+}$ concentrations. Descriptions that include $\mathrm{O}_{2}$ and $\mathrm{pH}$ data measured in such systems are, however, rare (Pierson et al., 1999; Wieland et al., 2005). We applied our model on data available for cyanobacterial mats from Chocolate Pots (Yellowstone National Park, US) (Pierson et al., 1999) and a saline lake from Camargue, France (Wieland et al., 2005) using the reported $\mathrm{pH}, \mathrm{O}_{2}$ and $\mathrm{Fe}^{2+}$ concentrations. The calculated halflife of $\mathrm{Fe}^{+2}$ at the surface of the mats described by Pierson et al. (1999) ranges between 19 and $35 \mathrm{~ms}$. Since the data provided by these authors do not include $\mathrm{pH}$ and $\mathrm{O}_{2}$ profiles in the water column above the mats, full iron profiles could not be reconstructed. Interestingly, the same study reported stimulation of $\mathrm{O}_{2}$ production by an increasing concentration of $\mathrm{Fe}^{2+}$, similar to what we have found for the cyanobacteria from our non-aerated $\mathrm{Fe}^{2+}$-rich reactor. With respect to the Camargue saline lake, $\mathrm{Fe}^{2+}$ diffuses toward the cyanobacterial populations at the surface of the mats from deeper sediment layers (Wieland et al., 2005). The lake water is oxic and has a $\mathrm{pH}>8.9$, thus $\mathrm{Fe}^{2+}$ would not be stable under these conditions (Morgan and Lahav, 2007). Nevertheless, calculated half-life of $\mathrm{Fe}^{2+}$ in these mats ranges between 2 and $8 \mathrm{~ms}$. In both cases the short (calculated) half-life of $\mathrm{Fe}^{2+}$ in the microenvironment of the cyanobacteria suggests that they are not exposed to high concentration of $\mathrm{Fe}^{2+}$.

We propose that cyanobacteria living in benthic communities in $\mathrm{Fe}^{2+}$-rich environments require high photosynthesis rates to avoid self-encrustation in iron precipitates. This attribute combined with mass transfer resistance will lead to elevated $\mathrm{pH}$ and $\mathrm{O}_{2}$ concentrations, which will form a barrier that prevents $\mathrm{Fe}$ from precipitating directly on the cells. Coupled with the flow conditions of natural water bodies the majority of the abiotically precipitated iron will be dispersed by the water. The high rate of photosynthesis will ensure that the barrier will be established within seconds to minutes in case flow conditions or iron concentrations in the ambient water are fluctuating.

Under the experimental conditions in the Äspö HRL, the barrier is present continuously because of the uninterrupted exposure to light, which would not be the case under natural conditions due to diurnal light fluctuations. Nevertheless, such light fluctuations should not have a significant effect on the ability of cyanobacteria to prevent self-encrustation in iron. $\mathrm{Fe}^{2+}$-rich environments, such as the one in the Äspö HRL, typically have 
very low $\mathrm{O}_{2}$ concentrations (Pierson et al., 1999; Ionescu et al., 2014a). Thus, in the dark, when there is no photosynthetic activity, the microenvironment in the cyanobacterial biofilms will rapidly turn anoxic due to the combined effects of respiration and mass transfer resistance, and the cells will not face an encrustation problem. The need for a protection mechanism against iron encrustation returns as soon as the photosynthetic activity resumes upon onset of illumination. Here, a high rate of photosynthesis to minimize the exposure time to high $\mathrm{Fe}^{2+}$ while producing $\mathrm{O}_{2}$ will be essential.

In addition to iron self-encrustation, cyanobacteria from $\mathrm{Fe}^{2+}$-rich environments need to deal also with $\mathrm{Fe}^{2+}$ toxicity (Brown et al., 2005; Shcolnick and Keren, 2006). While the ironbarrier provides a protection against iron toxicity during day time, it will have no effect in the dark. Therefore, we suggest that these cyanobacteria require a second mechanism to deal with the high $\mathrm{Fe}^{2+}$ concentrations at night, such as elaborate metal export systems (Shcolnick et al., 2009).

Single cells or biofilms below a critical biomass appear to get encrusted in iron (Pierson et al., 1999). The amount of biomass necessary to create the suggested "iron barrier" probably cannot be reached under the conditions in which the cells would need such a barrier. Hence, we suggest that new biofilms of the required critical biomass are formed in a " $\mathrm{Fe}^{2+}$ neutral" environment (e.g., floating on the surface or on the shores of a water body). When such biofilms become permanently exposed to high $\mathrm{Fe}^{2+}$, their survival is determined by the rapid achievement of a steady state in the distribution of $\mathrm{Fe}^{2+}$ in the microenvironment around the biofilms. This in turn depends on biomass, the overall photosynthesis rate of the biofilms and the ability of the biofilms to respond to the change in $\mathrm{Fe}^{2+}$ concentrations. This also suggests that a biofilm that contains a critical biomass of "iron tolerant cyanobacteria" may shelter less tolerant species, which could explain the observed partial overlap between the cyanobacterial communities from the aerated and non-aerated $\mathrm{Fe}^{2+}$-rich reactors.

The ability of cyanobacteria to survive in $\mathrm{Fe}^{2+}$-rich environments without getting encrusted while at the same time facilitating precipitation of iron oxides through their $\mathrm{O}_{2}$ producing photosynthetic activity may have implications for our understanding of early Earth geology. Cyanobacteria have been often suggested to be involved in the creation of the banded iron formations (BIF), the largest Fe depositions on Earth. Whether their impact was directly in the water body (Cloud, 1965, 1973) or indirectly by oxygenation of the atmosphere remains controversial (Cloud, 1968). However, despite cyanobacterial microfossils being found in BIFs (Cloud, 1965), the overall abundance of organic matter is scarce (Bontognali et al., 2013). If cyanobacteria were directly involved in the formation of BIFs, the existence of a cyanobacterial protective "iron barrier" may explain the lack of biomass in the Fe precipitates. Such a barrier mechanism would prevent the cyanobacteria from becoming entrapped in the precipitated iron. The $\mathrm{Fe}^{2+}$ supplied from the deep primordial ocean (Wang et al., 2009) would have been oxidized in the water column below the chlorophyll maximum and sink down as particulate $\mathrm{Fe}$ (III) without the carryover of biomass. Intuitively, marine cyanobacteria appear to be suitable model organisms to study the existence of such a mechanism. Nevertheless, modern oceans have been poor in iron for about $2 \mathrm{Ga}$, a substantial period for evolutionary adaptation, which makes it unlikely for marine cyanobacteria today to be adapted to such elevated $\mathrm{Fe}^{2+}$ concentrations. Hence, in this case, cyanobacteria from brackish-saline, iron-rich environments such as the Äspö HRL still provide the best model organisms for studying ancient Earth marine analogs.

\section{ACKNOWLEDGMENTS}

We are grateful to the SKB staff for technical, logistical, and analytical support at the Äspö HRL. Joachim Reitner is acknowledged for the initiation of the project "Biomineralisation, Biogeochemistry and Biodiversity of chemolithotrophic Microorganisms in the Tunnel of Äspö (Sweden)," which provided funding for this study through the DFG (German Research Foundation) research unit FOR 571. We thank the reviewers for valuable comments that helped improve the manuscript.

\section{SUPPLEMENTARY MATERIAL}

The Supplementary Material for this article can be found online at: http://www.frontiersin.org/journal/10.3389/fmicb.2014. 00459/abstract

Figure S1 | Pictures of an aerated (A) and a non-aerated (B) reactor set up in the ÄSPÖ Hard Rock Laboratory. The draining tube of the non-aerated reactor was bended such that flow-through was obtained only when the reactor was full to the top.

Figure S2 | (A) Experimental setup for laboratory microsensor measurements. $\mathrm{N}_{2}$-purged medium was run through a small flow chamber $(\mathrm{V} \sim 5 \mathrm{ml}$ ) (B) in which filters overgrown with cyanobacterial biofilms were placed and measured using microsensors (C).

Figure S3 | Maximum Likelihood tree of cyanobacterial sequences from the different reactors together with reference sequences. The sequences are labeled according to their origin: $1327 \mathrm{R} 1$ and $\mathrm{R} 2$ for the $\mathrm{Fe}^{2+}$-rich aerated and non-aerated reactors, respectively; TASF R1 for the $\mathrm{Fe}^{2+}$-poor aerated reactor. Bold labels were used in the case of larger clusters of sequences of measured cultures.

Figure $\mathrm{S} 4 \mid \mathrm{O}_{2}$ microprofiles measured in the cyanobacterial biofilms in the aerated and non-aerated $\mathrm{Fe}^{2+}$-rich reactors in the dark (filled symbols) and at incident irradiance of $60 \mu \mathrm{mol}$ photons $\mathrm{m}^{-2} \mathrm{~s}^{-1}$ (open symbols). The bars represent gross photosynthesis rates (in $\mu \mathrm{M} \mathrm{O}_{2} \mathrm{~s}^{-1}$ ) as measured by the light-dark-shift method in $100 \mu \mathrm{m}$ steps in the biofilm. All

measurements were done in-situ.

Figure $\mathrm{S} 5 \mid \ln$-situ $\mathrm{O}_{2}$ and $\mathrm{pH}$ microprofiles measured in the cyanobacterial biofilm from the aerated $\mathrm{Fe}^{2+}$-poor reactor before and after the addition of $25 \mu \mathrm{M}$ of $\mathrm{Fe}^{2+}$ at time points indicated in the legend. All profiles were measured using similar light intensity as used in the reactors. The measurements were conducted outside of the reactor using the natural water. $\mathrm{N}_{2}$ gas was bubbled continuously to maintain anoxic conditions.

Figure S6 | Nanoscale Secondary lon Mass Spectrometry (nanoSIMS) analysis of a cyanobacterial enrichment culture and an iron oxidizing mat obtained from the non-aerated $\mathrm{Fe}^{2+}$-rich reactor and incubated with

${ }^{57} \mathrm{Fe}^{2+}$. The Secondary electron panels $(\mathbf{A}, \mathbf{C})$ show the surface topography with color bar representing signal intensity. No enrichment with ${ }^{57} \mathrm{Fe}^{2+}$ can be seen near or on the cyanobacterial filaments (B), while an overall high concentration of ${ }^{57} \mathrm{Fe}^{2+}$ was detected in the iron oxidizing mat including a highly enriched single filament (D). 


\section{REFERENCES}

Arunasri, K., Sasikala, C., Ramana, C. V., Süling, J., and Imhoff, J. F. (2005). Marichromatium indicum sp. nov., a novel purple sulfur gammaproteobacterium from mangrove soil of Goa, India. Int. J. Syst. Evol. Microbiol. 55, 673-679. doi: 10.1099/ijs.0.02892-0

Atkins, P. W. (1978). Physical Chemistry, 1st Edn. Oxford: Oxford University Press.

de Beer, D., and Stambler, N. (2000). A microsensor study of light enhanced Ca2+ uptake and photosynthesis in the reef-building hermatypic coral Favia sp. Mar. Ecol. Prog. Ser. 194, 75-85. doi: 10.3354/meps 194075

Bontognali, T. R. R., Fischer, W. W., and Föllmi, K. B. (2013). Siliciclastic associated banded iron formation from the $3.2 \mathrm{Ga}$ Moodies Group, Barberton Greenstone Belt, South Africa. Precambrian Res. 226, 116-124. doi: 10.1016/j.precamres.2012.12.003

Brown, I. I., Bryant, D. A., Casamatta, D., Thomas-Keprta, K. L., Sarkisova, S. A., Shen, G., et al. (2010). Polyphasic characterization of a thermotolerant siderophilic filamentous cyanobacterium that produces intracellular iron deposits. Appl. Environ. Microbiol. 76, 6664-6672. doi: 10.1128/AEM.00 662-10

Brown, I. I., Mummey, D., and Cooksey, K. E. (2005). A novel cyanobacterium exhibiting an elevated tolerance for iron. FEMS Microbiol. Ecol. 52, 307-314. doi: 10.1016/j.femsec.2004.11.020

Chan, C. S., Fakra, S. C., Edwards, D. C., Emerson, D., and Banfield, J. F. (2009). Iron oxyhydroxide mineralization on microbial extracellular polysaccharides. Geochim. Cosmochim. Acta 73, 3807-3818. doi: 10.1016/j.gca.2009. 02.036

Cloud, P. (1973). Paleoecological significance of the banded iron formation. Econ. Geol. 68, 1135-1143. doi: 10.2113/gsecongeo.68.7.1135

Cloud, P. E. (1965). Significance of the gunflint (Precambrian) microflora: photosynthetic oxygen may have had important local effects before becoming a major atmospheric gas. Science 148, 27-35. doi: 10.1126/science.148. 3666.27

Cloud, P. E. (1968). Atmospheric and hydrospheric evolution on the primitive earth: both secular accretion and biological and geochemical processes have affected earth's volatile envelope. Science 160, 729-736. doi: 10.1126/science.160.3829.729

Cohen, Y., Jørgensen, B. B., Revsbech, N. P., and Poplawski, R. (1986). Adaptation to hydrogen sulfide of oxygenic and anoxygenic photosynthesis among Cyanobacteria. Appl. Environ. Microbiol. 51, 398-407.

Davies, C. W. (1962). Ion Association. Washington, DC: Butterworth.

Fortin, D., and Langley, S. (2005). Formation and occurrence of biogenic iron-rich minerals. Earth-Sci. Rev. 72, 1-19. doi: 10.1016/j.earscirev.2005. 03.002

Fu, L., Niu, B., Zhu, Z., Wu, S., and Li, W. (2012). CD-HIT: accelerated for clustering the next-generation sequencing data. Bioinformatics 28, 3150-3152. doi: 10.1093/bioinformatics/bts565

Hegler, F., Schmidt, C., Schwarz, H., and Kappler, A. (2010). Does a low-pH microenvironment around phototrophic $\mathrm{Fe}(\mathrm{II})$-oxidizing bacteria prevent cell encrustation by Fe(III) minerals? FEMS Microbiol. Ecol. 74, 592-600. doi: 10.1111/j.1574-6941.2010.00975.X

Huang, Y., Niu, B., Gao, Y., Fu, L., and Li, W. (2010). CD-HIT suite: a web server for clustering and comparing biological sequences. Bioinformatics 26, 680-682. doi: 10.1093/bioinformatics/btq003

Ionescu, D., Heim, C., Polerecky, L., Ramette, A., Häusler, S., Bizic-Ionescu, M., et al. (2014a). Diversity of iron oxidizing and reducing bacteria in flow reactors in the Äspö Hard Rock Laboratory. Geomicrobiol. J. (in press).

Ionescu, D., Heim, C., Polerecky, L., Thiel, V., and de Beer, D. (2014b). Biotic and abiotic oxidation and reduction of iron at circumneutral $\mathrm{pH}$ are inseparable processes under natural conditions. Geomicrobiol. J. (in press).

Ionescu, D., Siebert, C., Polerecky, L., Munwes, Y. Y., Lott, C., Häusler, S., et al. (2012). Microbial and chemical characterization of underwater fresh water springs in the Dead Sea. PLoS ONE 7:e38319. doi: 10.1371/journal.pone.0038319

Khalil, M., Teunissen, C., and Langkammer, C. (2011). Iron and neurodegeneration in multiple sclerosis. Mult. Scler. Int. 2011:606807. doi: 10.1155/2011/ 606807

Laaksoharju, M., Tullborg, E., Wikberg, P., Wallin, B., and Smellie, J. (1999). Hydrogeochemical conditions and evolution at the Äspö HRL, Sweden. Appl. Geochemistry 14, 835-859. doi: 10.1016/S0883-2927(99) 00023-2
Lane, D. (1991). “16S/23S rRNA sequencing,” in Nucleic Acid Techniques in Bacterial Systematics, eds E. Stackebrandt and M. Goodfellow (New York; Chichester: John Wiley and Sons), 115-175.

Lewy, Z. (2012). Banded iron formations (BIFs) and associated sedediments do not reflect the physical and chemical properties of early precambrian seas. Int. J. Geosci. 03, 226-236. doi: 10.4236/ijg.2012.31026

Morgan, B., and Lahav, O. (2007). The effect of $\mathrm{pH}$ on the kinetics of spontaneous $\mathrm{Fe}(\mathrm{II})$ oxidation by $\mathrm{O}_{2}$ in aqueous solution-basic principles and a simple heuristic description. Chemosphere 68, 2080-2084. doi: 10.1016/j.chemosphere.2007.02.015

Olson, J. M. (2006). Photosynthesis in the Archean era. Photosynth. Res. 88, 109-117. doi: 10.1007/s11120-006-9040-5

Oren, A., Ionescu, D., Lipski, A., and Altendorf, K. (2005). Fatty acid analysis of a layered community of cyanobacteria developing in a hypersaline gypsum crust. Arch. Hydrobiol. Suppl. Algol. Stud. 117, 339-347. doi: 10.1127/18641318/2005/0117-0339

Parenteau, M. N., and Cady, S. L. (2010). Microbial piosignatures in iron-mineralized phototrophic mats at Chocolate Pots hot springs, Yellowstone National Park, United States. Palaios 25, 97-111. doi: 10.2110/palo.2008.p08-133r

Pierson, B. K., and Parenteau, M. N. (2000). Phototrophs in high iron microbial mats: microstructure of mats in iron-depositing hot springs. FEMS Microbiol. Ecol. 32, 181-196. doi: 10.1111/j.1574-6941.2000.tb00711.x

Pierson, B. K., Parenteau, M. N., and Griffin, B. M. (1999). Phototrophs in highiron-concentration microbial mats?: physiological ecology of phototrophs in an iron-depositing hot spring. Appl. Environ. Microbiol. 65, 5474-5483.

Polerecky, L., Adam, B., Milucka, J., Musat, N., Vagner, T., and Kuypers, M. M. M. (2012). Look@NanoSIMS-a tool for the analysis of nanoSIMS data in environmental microbiology. Environ. Microbiol. 14, 1009-1023. doi: 10.1111/j.14622920.2011.02681.x

Quast, C., Pruesse, E., Yilmaz, P., Gerken, J., Schweer, T., Yarza, P., et al. (2012). The SILVA ribosomal RNA gene database project: improved data processing and web-based tools. Nucleic Acids Res. 41, 1-7. doi: 10.1093/nar/ gks1219

Revsbech, N., and Jorgensen, B. B. (1981). Primary production of microalgae in sediments measured by oxygen microprofile, $\mathrm{H} 14 \mathrm{CO} 32$ fixation and oxygen exchange methods. Limnol. Oceangr. 26, 717-730. doi: 10.4319/lo.1981.26.4.0717

Revsbech, N. P. (1989). An oxygen microsensor with a guard cathode. Limnol. Oceanogr. 34, 474-478. doi: 10.4319/lo.1989.34.2.0474

Riemer, J., Hoepken, H. H., Czerwinska, H., Robinson, S. R., and Dringen, R. (2004). Colorimetric ferrozine-based assay for the quantitation of iron in cultured cells. Anal. Biochem. 331, 370-375. doi: 10.1016/j.ab.2004.03.049

Rippka, R., Deruelles, J., Waterbury, J. B., Herdman, M., and Stanier, R. Y. (1979). Generic assignments, strain histories and properties of pure cultures of cyanobacteria. J. Gen. Microbiol. 111, 1-61. doi: 10.1099/00221287-111-1-1

Saini, G., and Chan, C. S. (2013). Near-neutral surface charge and hydrophilicity prevent mineral encrustation of Fe-oxidizing micro-organisms. Geobiology 11, 191-200. doi: 10.1111/gbi.12021

Shcolnick, S., and Keren, N. (2006). Metal homeostasis in cyanobacteria and chloroplasts. Balancing benefits and risks to the photosynthetic apparatus. Plant Physiol. 141, 805-810. doi: 10.1104/pp.106.079251

Shcolnick, S., Summerfield, T. C., Reytman, L., Sherman, L. A., and Keren, N. (2009). The mechanism of iron homeostasis in the unicellular cyanobacterium synechocystis sp. PCC 6803 and its relationship to oxidative stress. Plant Physiol. 150, 2045-56. doi: 10.1104/pp.109.141853

Suzuki, T., Hashimoto, H., Matsumoto, N., Furutani, M., Kunoh, H., and Takada, J. (2011). Nanometer-scale visualization and structural analysis of the inorganic/organic hybrid structure of Gallionella ferruginea twisted stalks. Appl. Environ. Microbiol. 77, 2877-2881. doi: 10.1128/AEM. 02867-10

Van Veen, W. L., Mulder, E. G., and Deinema, M. H. (1978). The SphaerotilusLeptothrix group of bacteria. Microbiol. Rev. 42, 329-356.

Ventura, S., Viti, C., Pastorelli, R., and Giovannetti, L. (2000). Revision of species delineation in the genus Ectothiorhodospira. Int. J. Syst. Evol. Microbiol. 50, 583-591. doi: 10.1099/00207713-50-2-583

Wang, Y., Xu, H., Merino, E., and Konishi, H. (2009). Generation of banded iron formations by internal dynamics and leaching of oceanic crust. Nat. Geosci. 2, 781-784. doi: 10.1038/ngeo652 
Wieland, A., Zopfi, J., Benthien, M., and Kühl, M. (2005). Biogeochemistry of an iron-rich hypersaline microbial mat (Camargue, France). Microb. Ecol. 49, 34-49. doi: 10.1007/s00248-003-2033-4

Yuan-Hui, L., and Gregory, S. (1974). Diffusion of ions in sea water and in deep-sea sediments. Geochim. Cosmochim. Acta 38, 703-714. doi: 10.1016/00167037(74)90145-8

Conflict of Interest Statement: The authors declare that the research was conducted in the absence of any commercial or financial relationships that could be construed as a potential conflict of interest.

Received: 03 June 2014; accepted: 13 August 2014; published online: 02 September 2014.
Citation: Ionescu D, Buchmann B, Heim C, Häusler S, de Beer D and Polerecky L (2014) Oxygenic photosynthesis as a protection mechanism for cyanobacteria against iron-encrustation in environments with high $\mathrm{Fe}^{2+}$ concentrations. Front. Microbiol. 5:459. doi: 10.3389/fmicb.2014.00459

This article was submitted to Aquatic Microbiology, a section of the journal Frontiers in Microbiology.

Copyright (c) 2014 Ionescu, Buchmann, Heim, Häusler, de Beer and Polerecky. This is an open-access article distributed under the terms of the Creative Commons Attribution License (CC BY). The use, distribution or reproduction in other forums is permitted, provided the original author(s) or licensor are credited and that the original publication in this journal is cited, in accordance with accepted academic practice. No use, distribution or reproduction is permitted which does not comply with these terms. 